\title{
ДОСЛІДЖЕННЯ ПИТАНЬ ВИКОРИСТАННЯ МЕХАНІЗОВАНОГО ВІДДІЛЕННЯ ЯК САМОСТІЙНОї БОЙОВОЇ ОДИНИЦІ
}

Розглянуті проблемні питання використання механізованого відділення як автономного (самостійного) підрозділу для виконання бойових задач у певній обстановці на основі досвіду ведення бойових дій у сучасних війнах та військових конфліктах. Проведено аналіз і обгрунтування окремих факторів організаційної диференціації використання механізованого відділення як самостійної бойової одиниці. Врахування таких факторів дозволить підвищити активність, рівень підготовки, актуальність думки та персональні характеристики командного складу окремого підрозділу (механізованого відділення), щзо безпосередньо впливають на його боєздатність. Це дозволить більи ефективно використовувати окремі підрозділи (механізовані відділення) під час виконання поставленого бойового завдання у сучасних військових конфліктах. Розглянуто основні особливості (фактори) ведення бойових дій механізованим відділенням як самостійної бойової одиниці.

Ключові слова: механізоване відділення, збройні конфлікти, всебічне забезпечення, фактори.

\section{Вступ}

Постановка проблеми. Дефіцит свободи ведення бойових дій, ініціативності особового складу у плануванні дій, відсутність постійного всебічного забезпечення за більшістю напрямків, нестача різноманітних засобів бойової підтримки та методів ефективного зв'язку в сучасних умовах протидії 3 боку противника призводить до обмеженого використання механізованого відділення як самостійної бойової одиниці. Однак, використання механізованого відділення як самостійної бойової одиниці містить ряд переваг: збільшує швидкість прийняття рішень (підвищує оперативність управління підрозділом); дозволяє оптимізувати сили та засоби для вирішення окремого тактичного завдання [1-2]. Ці переваги дозволяють підвищити живучість і ефективність механізованих відділень як самостійної бойової одиниці.

Аналіз останніх досліджень і публікацій. У відкритій літературі є джерела, які присвячені дослідженню питань аналізу правил створення та бойового застосування окремих тактичних груп різного призначення [3-7].

Дослідженню перспектив розвитку та бойового застосування сухопутних військ і їх складових підрозділів присвячені роботи [3-4]. В цих роботах визначається, що ядром сухопутних військ армії США в майбутньому стане окрема бригадна тактична група. Такий підрозділ розглядається як “сила безпосередньої дії” тактичного рівня. Відповідно до конкретного призначення всі окремі бригадні тактичні групи поділяють на такі: групи сил спеціальних операцій; піхотний полк “Randger”; повітрянодесан- тні та легкі піхотні підрозділи; підрозділи перехідного періоду типу "Striker" (із залученням бойових машин піхоти типу “Striker”); “важкі” формування (бронетанкові та механізовані підрозділи); повітряно-штурмові підрозділи. Бригадні групи (бригади) нового типу повинні бути спроможні проводити самостійні бойові дії впродовж кількох діб після прибуття в район оперативного призначення без додаткової підготовки та забезпечення. Характерною рисою перспективних бригад (бригадних груп) $\epsilon$ наявність в їх складі необхідного комплекту формувань меншого масштабу різних родів військ в усіх ланках i, як слідство, їх самостійність при вирішенні поставлених завдань [5]. Відмічається, що в результаті реформування на рубежі 2020-2032 рр. бригади сухопутних військ армії США будуть мати модульну структуру та будуть спроможні діяти як самостійно в звичайному (штатному) форматі, так і у випадку необхідності їх дроблення для автономного проведення підрозділами меншого масштабу тих або інших конкретних акцій, перш за все антитерористичних. Залежно від поставлених завдань модулі різної організації та призначення - відділення, секції, взводи, роти, батальйони, зведені в бригадні бойові (а іноді й забезпечуючі) групи - будуть передаватися в підпорядкування командирам об'єднаних оперативних формувань для дії за їх планами [5].

Для вирішення завдань проведення розвідувально-пошукових, рейдових, блокувальних дій або штурмових дій, здійснення обходів, охорони важливих об'єктів і комунікацій, супроводження колон, можуть створюватися батальйонні (ротні) тактичні групи [5-6]. Батальйонні тактичні групи створю- 
ються у складі механізованого (танкового) батальйону, посиленого танковою (механізованою) ротою, артилерійським дивізіоном (батареєю), інженерносаперною ротою (взводом), розвідувальним взводом та іншими підрозділами. Ротна тактична група складається 3 механізованої (танкової) роти, посиленої механізованим (танковим) взводом, артилерійським (мінометним) взводом, інженерно-саперним відділенням та іншими підрозділами.

У роботах [6-7] проведені системні дослідження, присвячені питанням визначення факторів, які впливають на створення тактичних груп для виконання конкретних бойових завдань. У роботі [6] аналізуються дії тактичних угруповань військ, бригадних, полкових, батальйонних і ротних тактичних груп зі складу оперативних (оперативно-тактичних) угруповань військ уході локальних війн і збройних конфліктів.

У роботах [8-11] проведені дослідження щодо оцінювання окремих вогневих показників як стрільців, так і вогневих підрозділів.

Недоліком зазначених робіт $є$ те, що бойові підрозділи, які досліджуються, мають значні по кількості сили та засоби. Ці підрозділи діють під чітким керівництвом штабу окремої групи та мають умовну автономність. При появі “нештатних ситуацій” (потрапляння у засідку, втрата зв’язку або підрозділів вогневої підтримки) такі великі бойові групи представляють собою добру мішень для противника. Тому, для підвищення живучості та ефективності механізованих відділень пропонується застосовувати їх як самостійні бойові одиниці. Цьому питанню присвячена дана робота.

Метою статті $є$ дослідження окремих питань використання механізованого відділення поза взводом і вироблення пропозицій щодо оцінки ефективності таких дій.

\section{Виклад основного матеріалу}

Розглянемо основні особливості ведення бойових дій механізованим відділенням як самостійної бойової одиниці.

\section{Базові фрактори ефективності ведення бойових дій механізованим відділенням}

Для зручності визначення перспективності введення інноваційних методів управління механізованим відділенням необхідно проаналізувати основні фактори бойової ефективності такого підрозділу під час ведення бойових дій у сучасних умовах за досвідом останніх конфліктів у світі та під час Операції об'єднаних сил (Антитерористичної операції) на сході України [12-14].

\section{Категорії факторів.}

\section{Фактори бойової комунікації}

До факторів бойової комунікації прийнято від- носити можливість відділення до самоуправління або взаємодії з іншими відділеннями чи своїми автономними частинами за допомогою матеріальнотехнічних або тактично-біологічних засобів передачі інформації за для забезпечення сталого ефективного бойового взаємозв'язку.

До цієї категорії відносяться такі фактори:

1) дальність бойової комунікації між частинами одного підрозділу;

2) ефективність та швидкість оптимальної комунікації, що не впливає на злагоджені дії підрозділу;

3) комунікативна злагодженість під час виконання бойового завдання;

4) комунікативна злагодженість під час взаємодії з іншими підрозділами та пунктами віддаленого управління чи планування;

5) стала здатність до ефективної взаємодії з різнобічними засобами підтримки та забезпечення підрозділу;

6) здатність до відновлення розірваної комунікації між частинами чи автономними частинами підрозділу в умовах бойового застосування військ (сил);

7) здатність до протидії підрозділом ворожим засобам постановки радіозавад.

\section{Фактори бойової злагодженості}

До факторів бойової злагодженості прийнято відносити можливість відділення до правильних тактично-оперативних дій в умовах бойового зіткнення або на марші з максимально ефективним використанням особового складу, озброєння та техніки, їх особливостей, різниці із ворожими зразками, опираючись на вміння та навички особового складу підрозділу та його безпосередніх командирів для успішного виконання бойового або тактичного завдання.

До цієї категорії відносяться такі фактори:

1) ефективність використання озброєння;

2) особисті навички кожного військовослужбовця відділення;

3) комбінована здатність щодо вогневого потенціалу відділення;

4) бойовий досвід;

5) формування структури та порядку взаємодії між частинами (групами, особами, вогневими засобами, що мають обслугу) відділення;

6) методологія проведення маневру;

7) здатність до протидії факторам, що сприяють пониженню злагодженості підрозділу.

\section{Фактори вогневої ефективності}

До факторів вогневої ефективності прийнято відносити ряд факторів, що несуть безпосередній вплив на кількість, потужність, щільність вогню та перемінну сталу цих показників, що забезпечують 
підрозділу вогневу активність та здатність до використання базових та спеціальних маневрів вогнем, підрозділом під час виконання бойового або тактичного завдання.

До цієї категорії відносяться такі фактори:

1) наявна кількість озброєння та техніки;

2) кількість боєприпасів та засобів для здійснення вогневого контакту та вогневої дії;

3) швидкострільність озброєння та темп стрільби відділення;

4) наявність у підрозділу штатних засобів боротьби з технікою, фортифікаційними спорудами та авіацією противника;

5) наявність методів далекого гранатометання;

6) наявність у підрозділу засобів оптичного корегування та прямого наведення зброї;

7) наявність постійної відпрацьованої структури стрільби та відповідність щодо неї наявного озброєння.

\section{Фактор організаційної диференціації}

До факторів організаційної диференціації прийнято відносити активність, рівень підготовки, актуальність думки та персональні характеристики командного складу підрозділу, що безпосередньо впливають на його боєздатність та можуть стати причиною більш ефективного чи негативного розвитку та використання підрозділом інших сфер та факторів бойової ефективності під час виконання поставленого завдання.

До цієї категорії відносяться такі фактори:

1) особистий авторитет командного складу;

2) рівень тактичних та оперативно-тактичних навичок управління підрозділом;

3) особисті навички командира;

4) аналітичні здібності командного та особового складу;

5) наявність двостороннього зв'язку між особовим складом і системами управління.

Типові проблемні питання для бойової комунікації механізованого відділення Збройних Сил України:

1) відсутність прогресивних засобів бойової комунікації, що призводить до:

- пониження мобільності підрозділу через неможливість визначення об'єктивної тактичної обстановки підрозділом;

- можливість заглушення зв'язку чи перехоплення важливої інформації противником;

- можливість викриття своїх позицій ворогові (у разі роботи з незахищеними засобами бойової комунікації підрозділу);

2) відсутність альтернативних схем реалізації бойової комунікації підрозділу:

- можливість розриву бойової комунікації в середині бойового шикування підрозділу (у випадку втрати центральної трійки);

- можливість обходу противником з флангу за рахунок неможливості проникаючого огортання бойових порядків підрозділу;

- подібний тип регуляції вогню, що в основному опирається на вогневу групу відділення;

3) відсутність вогневої комунікації у випадках незвичних тактичних операцій чи умов бою:

- не прорахована автономність частин та вогневих засобів відділення в умовах, де 3 міркувань заняття ефективних позицій відкриття вогню та маскування необхідно сформувати кілька автономних вогневих груп;

- не продумана система заходів щодо комплексних дій малих підрозділів чи підрозділів, що понесли вагомі втрати 3 причин негативних (пагубних ) чинників бою;

- не гарантується вогнева комунікація поміж підрозділами, які діють на дистанції, що перевищує базову дистанцію вогневого контакту, маневру для відновлення вогневої комунікації та подібних аспектів, що базуються на відсутності вогневої комунікації.

Типові проблемні питання для бойової злагодженості механізованого відділення Збройних Сил України:

1) відсутність базових механізмів переформування чи екстреного залагодження підрозділів в умовах проведення бойових дій:

- не вироблена система об'єднання підрозділів, що втратили чи частково втратили, боєздатність в ситуативну збірну бойову групу, що зможе задовільнити потреби щодо опціональної здатності виконувати поставлене бойове завдання;

- відсутність системи боротьби з блокуванням певних частин підрозділів противником, що призводить до суттєвого падіння бойової злагодженості в цілому чи по фрагментах підрозділу;

- прописане доктринальне використання підрозділів тільки у безпосередніх зв'язках з підрозділами союзників, що виключає можливість чи здатність підрозділу до реорганізації без прикриття сусідів;

2) відсутність системи заміщення втрат без виведення підрозділу з зони бойових дій (прописаної системи):

- це унеможливлює здійснення планомірного звикання до умов місцевості, що негативно впливає на його фактор орієнтування у вказаному районі, формування тактичної орієнтаційної переваги над ворогом, досконального вивчення місцевості, формування ешелонованої, маскованої, правильної оборони чи фортифікаційних прихованих позицій та споруд для наступальних дій;

- послаблення щільності оборони або маневреного вогневого балансу у підрозділах, що призводить до падіння ефективності виконання бойових 
завдань, зменшення маневреності, вогневої потужності, здатності до вогневого протистояння;

- унеможливлення виконання підрозділами усіх покладених на них функцій та використання ними базових бойових формацій;

3) відсутність типових формацій переналаштування бойових функцій підрозділу:

- зменшення базової бойової підготовленості до екзотичних або не звичних умов бою, що в подальшому викликає ряд проблем, пов'язаних з іншими факторами бою;

- збільшення часу на перехід від одного типажу підрозділу до більш ефективного в даних умовах, що спричиняє нерівномірний, а в гіршому випадку не контрольований рух підрозділів на оперативній площині, що може призводити до здійснення ворогом обходів та охоплень, оточень та інших маневрів, пов'язаних з розривом бойової комунікації підрозділу $з$ тилом;

- зменшення мобільності підрозділу з причини неспроможності до перемін, порядку, форми, концепцій, руху військового підрозділу в умовах незвичних для типових прописаних концепцій.

Типові проблемні питання для вогневої ефективності механізованого відділення Збройних Сил України:

- застарілість засобів вогневої ефективності деяких зразків озброєння, що створюють рішучу вогневу перевагу над ворогом здебільше не надаються в оптимальному обсязі або надаються 3 недостатньою кількістю боєкомплекту;

- застарілість схем вогневої ефективності та формацій відділень, що пов'язанні з ними - відносна вогнева перевага на полі бою досягається неймовірно великою кількістю менших проте значущих факторів бою, тому використання єдиного незмінного шаблону ніколи не являлось оптимальним рішенням;

- неспроможність до адаптації вогневих засобів до індивідуальних умов бою, що призводить до неспроможності наших підрозділів під час довгого або надкороткотривалого зіткнення конкурувати з відділеннями країн НАТО;

- неможливість сковування засобів підтримки противника та протидії ним.

Типові проблеми для організаційної диферен- ціації:

- скутість форм взаємодії в середині підрозділу, відсутність детермінацій ефективної ініціативи, що в свою чергу призводить до падіння ефективності відділення в відриві від основних сил;

- відсутність сталих, відмінних алгоритмів дій для підрозділів у складі більших з'єднань та в відриві від них;

- відсутні або застарілі принципи маневрених дій малих груп (не спеціального призначення) - це пов'язане $з$ уявленням ще радянських доктриністів, які вважали, що такі дії - тип дій військ на терені наближення до партизанської боротьби);

- відсутність універсальних заходів бойової активності, що є ефективними і для малих і великих 3’єднань (підрозділів, одиниць);

- відсутні теоретико-аналітичні та емпіричні концепції взаємодії великих та малих, та надмалих 3'єднань в умовах зони відповідальності, театру бойових дій, зоні оперативного контролю.

Розв'язання обгрунтованих проблемних питань бойового застосування механізованого відділення як самостійної бойової одиниці дозволить підвищити живучість і автономність використання підрозділів у сучасних військових конфліктах.

\section{Висновок}

У роботі проведено дослідження питань використання механізованого відділення як самостійної бойової одиниці для підвищення живучості та автономності використання підрозділів у сучасних військових конфліктах.

Проведено аналіз і обгрунтування окремих факторів організаційної диференціації використання механізованого відділення як самостійної бойової одиниці. Врахування таких факторів дозволить підвищити активність, рівень підготовки, актуальність думки та персональні характеристики командного складу окремого підрозділу (механізованого відділення), що безпосередньо впливають на його боєздатність.

Це дозволить більш ефективно використовувати окремі підрозділи (механізовані відділення) під час виконання поставленого бойового завдання у сучасних військових конфліктах.

\section{Список літератури}

1. Поляков С. Ю., Лєнкін В. М., Зміївський Г. А., Шкуропацький О. І. Деякі аспекти удосконалення тактичної підготовки курсантів (студентів) військових підрозділів вищих навчальних закладів. Збірник наукових праць Харківського національного університету Повітряних Сил. 2014. № 1(38). С. 292-298.

2. Дробан О. М., Жохальський Е. Ф. Підходи до оцінки ефективності стрільби зі стрілецької зброї. Військовотехнічний збірник. 2018. № 19. С. 19-23. https://doi.org/10.33577/2312-4458.19.2018.19-23.

3. Ярош С. П., Рогуля О. В. Аналіз тактики бойового застосування крилатих ракет при нанесенні ударів по важливих державних об'єктах та угрупованнях військ. Збірник наукових працьь Харківського національного університету Повітряних Сил. 2019. № 3(61). С. 35-44. https://doi.org/10.30748/zhups.2019.61.06.

4. ADRP 3-0: Unified Land Operations. Washington : Headquarters Department of the Army Washington, 2012.74 p. 
URL: https://www.lsu.edu/hss/milsci/resources/adrp3_0.pdf (accessed 01.06.2021).

5. Гурін О. М. Проведення аналізу шляхів формування обгрунтованого раціонального варіанту тилового забезпечення бойових дій Повітряних Сил Збройних Сил України. Збірник наукових пращь Харківського національного університету Повітряних Сил. 2016. № 1(46). С. 37-40.

6. JP 1-02. Department of Defense Dictionary of Military and Associated Terms. Washington : US Government Printing Office, 2010. 693 p. URL: https://irp.fas.org/doddir/dod/jp1_02.pdf (accessed 01.06.2021).

7. Ярош С. П., Гузченко С. В. Класифікація тактичних груп. Збірник наукових праць Харківського національного університету Повітряних Сил. 2016. № 3(48). С. 21-25.

8. Телелим В. М., Загорка О. М., Стрижевський В. В. Досвід створення та застосування угруповань військ (сил) у локальних війнах і збройних конфліктах другої половини XX та на початку XXI століття : монографія. Київ : НУОУ, 2012. $336 \mathrm{c}$.

9. Шмаков О. М. Словник офіцера внутрішніх військ з воєнно-наукових питань. Харків : Акад. ВВ МВС України, 2009. $518 \mathrm{c}$.

10. Kriukov O., Melnikov R., Bilenko O., Zozulia A., Herasimov S., Borysenko M., Pavlii V., Khmelevskiy S., Abramov D., Sivak V. Modeling of the process of the shot based on the numerical solution of the equations of internal ballistics. Eastern-European Journal of Enterprise Technologies. 2019. № 1(97). P. 40-46. https://doi.org/10.15587/17294061.2019.155357.

11. Zhuravlov O. O., Kolomiitsev O. V., Herasymov S. V. Method for determining coefficient power error of front resistance missile by means station outwardly trajectory measurements. Scientific Works of Kharkiv National Air Force University. 2017. Vol. 3(52). P. 72-76.

12. Журавльов О. О., Коломійцев О. В., Герасимов С. В., Чумак Б. О. Метод оцінки значення похибки коефіцієнта сили лобового опору снаряда за результатами зовнішньотраєкторних вимірювань. Озброєння та військова техніка. 2017. № 14(2). C. 29-33. https://doi.org/10.34169/2414-0651.2017.2(14).29-33.

13. Герасимов С. В., Журавльов О. О. Оцінка коефіцієнта лобового опору снаряда методами поліноміальної апроксимації та інтерполяції координат центра мас на етапі льотно-конструкторських випробувань. Озброєння та військова техніка. 2017. № 15(3). С. 30-34. https://doi.org/10.34169/2414-0651.2017.3(15).30-34.

14. Блащук С. В., Медінець I. Р. Негативні фактори, які впливають на ефективність використання механізованого відділення під час ведення бойових дій. Новітні технології - для захисту повітряного простору : зб. тез доп. XV наук. конф. курсантів та студентів Харківського національного університету Повітряних Сил ім. І. Кожедуба. Харків : ХНУПС ім. І. Кожедуба, 2019. С. 68-69.

15. Медінець I. Р., Качан М. В., Блащук С. В. Тактика та методика використання механізованого відділення для виконання мультифункціональних завдань під час ведення бойових дій. Новітні технології - для захисту повітряного простору : зб. тез доп. XV наук. конф. Харківського національного університету Повітряних Сил ім. I. Кожедуба. Харків : ХНУПС ім. І. Кожедуба. 2019. С. 29.

16. Булай А. М., Василенко В. В., Добровольський Д. Д., Кадубенко В. С., Скопінцев О. О. Оцінка ефективності стрільби зі стрілецької зброї по цілям з індивідуальним броньованим захистом. The scientific heritage. 2020. No. 49. Р. 4.

\section{Відомості про авторів:}

Медінець Іван Романович

старший викладач

Харківського національного університету

Повітряних Сил ім. І. Кожедуба,

Харків, Україна

https://orcid.org/0000-0003-0750-4423

\section{Лук'янов Сергій Миколайович}

старший викладач

Харківського національного університету

Повітряних Сил ім. І. Кожедуба,

Харків, Україна

https://orcid.org/0000-0001-8273-3504

\section{Шарапа Іван Андрійович}

викладач

Харківського національного університету

Повітряних Сил ім. І. Кожедуба,

Харків, Україна

https://orcid.org/0000-0003-0693-8035

\section{Information about the authors:}

Ivan Medinets

Senior Lecturer

of Ivan Kozhedub Kharkiv National

Air Force University,

Kharkiv, Ukraine

https://orcid.org/0000-0003-0750-4423

\section{Serhii Lukianov}

Senior Lecturer

of Ivan Kozhedub Kharkiv National

Air Force University,

Kharkiv, Ukraine

https://orcid.org/0000-0001-8273-3504

\section{Ivan Sharapa}

Lecturer

of Ivan Kozhedub

Kharkiv National Air Force University, Kharkiv, Ukraine

https://orcid.org/0000-0003-0693-8035 


\section{Блащук Сергій Вікторович}

курсант

Харківського національного університету

Повітряних Сил ім. І. Кожедуба,

Харків, Україна

https://orcid.org/0000-0003-2388-813X

\author{
Sergei Blaschuk \\ Cadet \\ of Ivan Kozhedub Kharkiv \\ National Air Force University, \\ Kharkiv, Ukraine \\ https://orcid.org/0000-0003-2388-813X
}

\section{ИССЛЕДОВАНИЕ ВОПРОСОВ ИСПОЛЬЗОВАНИЯ МЕХАНИЗИРОВАННОГО ОТДЕЛЕНИЯ КАК САМОСТОЯТЕЛЬНОЙ БОЕВОЙ ЕДИНИЦЫ}

И.Р. Мединец, С.Н. Лукьянов, И.А. Шарапа, С.В. Блащук

Рассмотрены проблемные вопросы использования механизированного отделения как автономного (самостоятельного) подразделения для выполнения боевых задач в определенной обстановке на основе опыта ведения боевых действий в современных войнах и военных конфликтах. Проведен анализ и обоснование отдельных факторов организационной дифференциации использования механизированного отделения как самостоятельной боевой единиць. Учет таких факторов позволит повысить активность, уровень подготовки, актуальность мысли и персональные характеристики командного состава отдельного подразделения (механизированного отделения), непосредственно влияющие на его боеспособность. Это позволит более эффективного использовать отдельные подразделения (механизированные отделения) при выполнении поставленной боевой задачи в современных военных конфликтах. Рассмотрены основные особенности (факторы) ведения боевых действий механизированным отделением как самостоятельной боевой единицы.

Ключевые слова: механизированное отделение, вооруженные конфликты, всестороннее обеспечение, факторы.

\section{RESEARCH OF ISSUES OF THE USE OF MECHANIZED SQUAD AS AN INDEPENDENT COMBAT UNIT}

I. Medinets, S. Lukianov, I. Sharapa, S. Blaschuk

The problematic issues of using a mechanized unit (squad) as an autonomous (independent) unit to perform combat tasks in a certain situation on the basis of the experience of combat operations in modern wars and military conflicts are considered. These are issues such as combat communication, combat coherence, organizational differentiation and fire efficiency of the mechanized unit (squad). The study of the use of the mechanized unit (squad) as an independent combat unit will assess the increase in survivability and autonomy of the use of units in modern military conflicts. The purpose of the article is to study some issues of using a mechanized unit (squad) outside the platoon and to make proposals for evaluating the effectiveness of such actions. The analysis and substantiation of separate factors of organizational differentiation of use of the mechanized squad as independent fighting unit is carried out. Taking into account such factors will increase the activity, level of training, relevance of opinion and personal characteristics of the command staff of a particular unit (mechanized unit), which directly affect its combat effectiveness. This will allow more efficient use of individual units (mechanized units) in the performance of combat missions in modern military conflicts. The main features (factors) of combat operations by a mechanized unit (squad) as an independent combat unit are considered. For the convenience of determining the prospects of introducing innovative methods of mechanized unit (squad) management, the analysis of the main factors of combat effectiveness of such a unit during combat operations in modern conditions based on the experience of recent conflicts in the world and during the Joint Forces Operation (Anti-terrorist operation) in eastern Ukraine.

Keywords: mechanized department, armed conflicts, comprehensive support, factors. 